\title{
The Influence of Audio-Visual Media On the Ability to Understand Up Space Students
}

\section{Umaru Zubairu}

Federal University of Technologi Minna

Email : uzubairu@gmail.com

\begin{abstract}
The purpose of this research is to determine the effect of audio-visual media in the understanding of wake space, to know the results of student learning in the field of study of mathematics as well as determine whether there is a significant influence between the influence of teaching using audio visual media on student learning outcomes in the field of study of Mathematics. The research instrument used was a test writing essay form test as much as 5 grains of matter to the pretest and 5 grains of matter to posttest. As the population in this research is all which amounted to 28 people and the sample in this research is all students as Respondents. From the analysis of the data obtained some findings that average To the average value of the pretest experiments $(67,79)$ and the average pretest before using the conventional method (51). while in post-test data after teaching using audio visual media for the average value of posttest (80.50) and the average value of teaching using conventional methods on the posttest is $(76,11)$. From the calculation between the $t$ with ttable if $-\mathrm{t} 1-1 / 2<\mathrm{t}<\mathrm{t} 1-1 / 2<$, where $-1,217<2,24<1,217$ then Based on this case, H0 is rejected while the Ha accepted which stated "There is a significant effect between teaching using audio visual media on the ability to understand up the space of students.
\end{abstract}

\section{Keywords : audio visual media on the ability to understand up space}

\section{INTRODUCTION}

Learning gained by students during the school should be in the form of experience that can be used for the provision of life and to survive. The task of a teacher is not just a matter of teaching (teaching) but with more emphasis on learn (learning) and educate. Learning does not only focus on knowledge alone. The direction of the learning should be focused on learning, such as: learning how to know, learning how to do, learning how to be, and learning how to live together (Sumarmo, 2005: 5).

To be able to solve the problem, surely someone must have problem solving abilities enough. According to Utari-Sumarmo (Soekisno, 2002:3), the importance of ownership mathematics problem solving ability in students is that problem solving ability is the purpose of teaching mathematics, even as the heart of mathematics. Problem solving is not just a goal of learning mathematics, but also is the main tool to do so (Wahyudin, 2003). Whereas in Curriculum 2004 (Depdiknas, 2003:6), also mentioned that the purpose of learning mathematics is to develop problem solving ability. Soedjadi (in Soekisno, 2002:4) also stated that, solving the problem needs attention in mathematics education. 
Based on field studies by the author, the ability of students in understanding the shape of the build space is low, students are less able to understand the components of the cube,beam,tube,pyramid,cone and ball so that the results obtained in the application form up space is not as expected. In other words, the result of understanding the build space of the students is low. In general, learning the wake of the room is performed with the technique of traditional learning, which have an impact on the saturation in the study. This technique is still popularly used until now. This is in accordance with the experience of the author when the view of some schools, there is still a lot of teachers use the technique of lectures and giving examples of questions to convey the learning material. On the technique of the lectures of the teacher spent a lot of time to convey the material. Students in this learning is viewed not knowing anything and only received a materials science student or recipient of information in passive learning hayal without giving examples that can be seen and heard. So this technique is less capable and less interesting to understand the learning material, wake up this space. Therefore, students feel bored and not be able to channel the talents or do it yourself so that the level of pemahammannya still low. To overcome these problems, the teacher should use a media that is able to attract and stimulate the interest of students in order to improve the understanding ability of students in understanding the build space . Media pembelajaran audio visual or it could be called props, this could be an option as one of the media that can be used to overcome the problems that have been described previously.

The meaning of mathematics learning media can be interpreted simply as a medium of communication that the contents of the message can be received through the senses of sight and hearing that the information is real and effective than the information conveyed only through words .

Based on the description above, the writer is interested to conduct a research with the title " the Influence of Audio-Visual Media On the Ability to Understand Up Space Students.

\section{RESEARCH METHODS}

\section{Learning Method The Audio-Visual Media}

Solomon (2001 : 11) states, " the Notion of audio-visual derived from the word " Audible " that can be heard and the "Visible " that can be seen. So, the audio-visual media is media that consists of the process of hearing hearing at once with vision. The audio-visual Media can convey information in a way that is more creative, or more real than conveyed through words. That $75 \%$ of human knowledge up to the brain through the senses of sight and the rest through the sense of hearing.

Arsyad (2007 : 30) states, " the Production and use of material absorption through the view and not entirely dependent upon the understanding of words or symbols that are similar".

The main traits of the audio-visual media : 
a. They usually present a dynamic visual.

b. Is the physical representation of the idea of real or abstract ideas.

c. Developed according to the principles of psychology behaviorism and cognitive.

From the above opinion can be concluded that the audio-visual media is a learning process that uses the hardware absorption through the sense of hearing and sense of sight. Learning Media is defined as all objects that become intermediaries in the occurrence of learning. In a process of teaching and learning, two elements which is very important is that the methods of teaching and teaching methods. The second aspect of this is related. The selection of one of the media of teaching will certainly affect the type of media learning tools, although there are still many other aspects that must be considered in choosing the media, among others, the learning objectives, the type of task and the response is controlled by the student after learning that takes place and the contact of learning, including the characteristics of the students. As stated by Hamalik (1986:4) in Arsyad (2006:4) that the communication will run smoothly with maximum results when using a tool called media communication. Meanwhile, according to Gagne and Briggs (1975:4) in Arsyad (2006:4) learning media includes tools that are physically used to convey the content of the teaching material, which consists of: the book, the tape recorder, Real Objects, video camera, video recorder, film, slide (picture frame), photos, images, graphics, television, and computer. In other words the media is a component of the learning resources or rides physical that contain instructional material environment of the students who can stimulate students to learn.

While the notion of media according to the National Education Association (National Education Association/NEA), quoted by Wijaya (1991:137) are forms komuniaksi both printed and audio-visual as well as crockery and media should be manipulated, it can be seen, heard and read. The prescribed limits of understanding the media here is that the media is anything that can be used to channel messages from the sender to the receiver so that it can stimulate the mind, feelings, attention and interest and attention of students in such a way so that the learning process occurs by itself and continues to grow in the motivation to learn. While the notion of media according to the National Education Association (National Education Association/NEA), quoted by Wijaya (1991:137) are forms komuniaksi both printed and audio-visual as well as crockery and media should be manipulated, it can be seen, heard and read. The prescribed limits of understanding the media here is that the media is anything that can be used to channel messages from the sender to the receiver so that it can stimulate the mind, feelings, attention and interest and attention of students in such a way so that the learning process occurs by itself and continues to grow in the motivation to learn.

Of the few opinions about the understanding of the media can be concluded that: (1) the Media is a tool that can help the learning process that serves to clarify the meaning of the message delivered so that teaching objectives can be achieved perfectly, (2) the Media acts as a stimulant to learn, and can foster motivation to learn so that students do not become bored in achieving the goals of learning, (3) As submitted by the teacher must use the media, the most used is the medium of verbal namely in the form of words spoken in front of the students, (4) Everything that is contained within the school, either human or not human which in the beginning were not involved in the process of teaching and learning once designed and used in such activities.

The Instrument Of Data Collection 
Data in accordance with this research is the data of student learning outcomes as well as an overview of the activities of teachers and students during the learning process. The tests used in this study is in the form of Prites and post test. Post test given at the end of teaching aims to determine the extent to which the results obtained by the students towards the subject matter is given.

The pretest consists of the 5 point about the essay form that has been validated and deserves to be tested as a proficiency test before beginning enacted good treatment by Conventional methods and teaching using audio visual media on the subject matter up Space.

Post test consists of 5 of the point about which the essay form in accordance with the indicators of learning that have been established, which should be completed by students with a specific time. To get a more accurate test in the research, first conducted test test. .

\section{RESULTS AND DISCUSSION}

\section{Description Of The Results Of Research}

To obtain data in this study, the authors use the test results to learn the form of the assignment of the task essei held pretest before beginning teaching and posttest after learning with the Conventional method and after the use of audio-visual media. With the instrument obtained data for the variable $\mathrm{X}$ (prites) before using the audio-visual media, and vareabele $\mathrm{y}$ (posttest) using audio-visual media.

\section{Findings and Discussion}

Research conducted starting on the date of 21 mei until June 7, 2017 or four meetings. Before the learning process begins conducted pretest. The results of the data analysis of the pretest showed that the initial ability of students in understanding the build space before using the audio-visual media gets the value of the average 67,79 while the pretest students before using the conventional method obtained an average score of 51 and. From these results it can be stated that the results of student learning is still relatively low, and there is a difference between the two, meaning that the pretest second is better than the pretest before the treatment is given. From the results of posttest on conventional methods and learning using audio-visual media obtained an average score of posttest experimental class that was taught using audio-visual media is 80,50 and the average value of students who are taught using conventional methods is 76,11 . So there is a difference in learning outcomes of students in teaching using audio visual media is higher than the learning using the Conventional method and the second the results of the tested normal, homogeneous and received through the hypothesis test.

Then from the results of the test of the difference between the two methods is concluded that learning by using the audio-visual media influence the transmittance of learning outcomes of students.

Based on the observations, which became the supporting factors in the implementation of learning by using the audio-visual media is:

1. The students were very excited and enthusiastic about learning in the classroom with the use of audio-visual media. They look more active and bold in expressing opinions, and looked earnestly pay attention to the material up space and do the tasks given by the teachers. 
2. A sense of responsibility and desire of the students to solve mathematical problems associated with the cube and beam work well.

The active participation of students in solving mathematical problems become more optimal.

\section{CONCLUSION}

Based on the results of research and data analysis, obtained the following conclusion:

1. The average pretest ability to understand up space, before using the audio-visual media is 67,79 and the value of the rta-average pretest before students get teaching with the use of conventional methods is 51 This means the ability to understand up space before taught by using audio visual media and conventional methods are at the level of Less and do not meet the setandard minimum completeness ( KKM)

2. The average posttest ability to understand up space students. the school year 2016/2017, which was taught by using audio visual media is 80,50 and the value of the rta-average posttest of the students after getting the teaching with the use of conventional methods is 76,18 means the ability to understand the build space of the students taught by using audio visual media and conventional methods are at a Good level and meet the standard of minimum completeness ( KKM )

3. There is a significant difference between the ability to understand up space on the eighth grade students., before using the audio-visual media and to be taught after using audio-visual media. Students who are taught by using audio visual media is better than students taught using conventional methods in the teaching of the build space.

4. From the calculation between the $\mathrm{t}$ with table if $-\mathrm{t}_{1-1 / 2 \alpha}<\mathrm{t}<\mathrm{t}_{1-1 / 2 \alpha}$, where $-1,217<2,24$ $<1,217$ then Based on this case, $\mathrm{H} 0$ is rejected while the Ha accepted which stated "There is a significant effect between teaching using audio visual media to mathematics learning outcomes of students in the understanding of wake space.

\section{REFERENCES}

Ibrahim, M., Rachmadiarti, F., Nur, M., dan Ismono. (2000). Pembelajaran Kooperatif. Surabaya: UNESA-University Press.

Johanes, Kastolan, dan Sulasim. 2005. Kompetensi Matematika Kelas 2 SMA Semester 1 (Program IPA). Jakarta: Yudhistira.

Hamalik, O, 2001, Pendidikan Guru Berdasarkan Pendekatan Kompetensi. Bandung : Bumi Aksara.

http ://www.google.com/2014/05/29/Bangun-Ruang/

Margono, S.Drs. 2009. Metodologi Penelitian Pendidikan. Jakarta: Rineka Cipta 
Riduwan (2009) Rumus dan Data Dalam Analisis Statistika. Cetakan Ke-3. Bandung : CV Alfabeta.

Ruseffendi. E.T. 1991. Dasar-Dasar Penelitian dan Bidang Non Eksakta Lainnya. Semarang: IKIP Semarang Press.

Ruseffendi, E.T. 1998. Statistika Dasar untuk Penelitian Pendidikan. Bandung: IKIP Bandung Press.

Suherman. E. 2003. Evaluasi Pengajaran Matematika. Bandung: UPI.

Sumarmo, U. (2005). Pembelajaran Matematika untuk Mendukung Pelaksanaan Kurikulum Tahun 2002 Sekolah Menengah. Disajikan dalam Seminar Pendidikan Matematika di FPMIPA Universitas Negeri Gorontalo

Utari-Sumarmo. 2002. Kemampuan Pemahaman dan Penalaran Matematika dengan Kemampuan Penalaran Logik Siswa dan Beberapa Unsur Proses Belajar Mengajar. Disertai Doktor pada PPS UPI Bandung 